\title{
Consumption in the web of local and global relations of dominance and belonging
}

Güliz Ger

In this essay I reflect on how consumption serves to build and resolve tensions amplified by globalization and, its escort, neoliberal marketization, in the so-called emerging markets, in particular in Turkey. When scholars allude to "globalization," or global consumer culture, there is typically an implicit opposition between the global versus the local. The foreign global is associated with change, modernity, novelty, innovation, commodification; the familiar local with tradition and stubbornly old or romantically authentic ways of life. In addition, there are internal tensions between, for example, the rural and the urban or the dominated and the dominant, which are impacted by transnational relations. Contrary to a position "that sees the local from the outside, as a place continuously impinged upon by and encapsulated within external forces" (Lambek, 2011, p. 200), I take the perspective of the local. I examine how the consumers in a locality experience their encounters with people, things, ideologies, and images global, within the structural enablers and disablers, and if and how their ways and patterns of consumption change or not; how they define and differentiate themselves from internal Others that emerge or become amplified with globalization. My deliberations are framed by two considerations: domination and affiliation dynamics in global-local and local-local relationships and the dialogue of change and continuity.

I discuss the main approaches in the literature and offer directions for future research on consumption. The works I cite are representative, but not comprehensive. The first section reviews the diverse consumer experiences of and responses to their global encounters, as they navigate local social structures, embedded in asymmetrical global flows and a structure of common differences (Wilk, 1995). The second section presents criticisms of hybridity and "flow speak."The third section focuses on the Others within the local as it navigates the global: the rural other, class-based Others, and multiple Others of the faithful or the Islamists in Turkey. Finally, I offer suggestions for research on consumption in a global world.

\section{Encounters of consumers in emerging markets with global products and ideas}

Emulation and resistance, along with their opposite predictions for global homogenization and heterogenization, have been the earliest accounts of consumer responses. The issues with these 
engendered diverse arguments such as mimicry, hybridity, global flows, local appropriations and recontextualization of things global, and reinvented traditions. Criticisms of "flowspeak" and hybridity speak have bred yet more intricate theses.

\section{Emulation and resistance and their discontents}

Emulation thesis, along the lines of linear convergence theories, viewed globalization akin to modernization-as-Westernization, as a wave that spreads from the origin, typically from the "West to the Rest." This spread is fueled at the individual level by the emulation of aspirational consumption lifestyles seen on television and films, which parade imaginaries and discourses of global neoliberal consumerist ethos and deeds. Imitative learning is expected to result in a homogenized (thus Westernized) world to which the locals will assimilate. Sometimes called Coca-colonization or McDonaldization (Ritzer, 1993), emulation-based diffusion view has a palpable reflection in the consumptionscapes all over the world where consumers are being bombarded by the Cokes, Levi's, Disney toys, and look-alike shopping malls (Abaza, 2001; Ger and Belk, 1996; Howes, 1996).

On the other hand, resistance thesis argues that locals will resist the global consumer culture and maintain their local, "traditional" patterns of consumption. Refusal to buy foreign products is one example where nationalist or religious ideologies deploy moral sensibilities to induce resistance. Consumer resistance has been framed by broader notions of "clash of civilizations" (Huntington, 1996) or McDonaldization and Jihad (Barber, 1996), which pit tribal - nationalist, ethnic, and religious - identities against global marketization, as forces which cannot co-exist. Furthermore, religious fundamentalism has been argued to be a threat to consumerist ideology (Turner, 1994). Hence, instead of homogenization, the prediction here is that the world will confront revitalized forms of nationalism, parochialism, and religious fundamentalisms that will challenge the Western hegemony.

Emulation and rejection accounts suffer from linear and essentialist logic. Moreover, they fail to explain observed consumption patterns. There is ample evidence that neither religion nor nationalism pose a challenge to global marketization and consumerism. The growth of Islamic markets, marketing, and fashions (Gökarıksel and Secor, 2009; Sandikci and Jafari, 2013; Sandikci and Ger, 2007, 2011; Sandikci and Rice, 2011), at the junction of global capitalism and global Islam, is an instantiation of the global condition and part and parcel of global capitalism and consumerism. Islam is very much embedded in and coexists with global markets, consumption, and, politics (Ger, 2013). Neoliberalism couples symbiotically with Islamism in Turkey and elsewhere (Karaman, 2013). As Karaman argues, while neoliberalism and Islamism are distinct normative political rationalities, they are collaborative logics. Besides, Islam is not the only tribalism that collaborates with global markets and consumerism. Hindu nationalism also seems to happily coexist with the form global marketization takes in India (Rajagopal, 2001).

Furthermore, particular observed forms of resistance and emulation defy their simple definitions. Consider voluntary simplicity, anti-consumption, and anti-brand movements. Consumers engaged in such movements in Turkey do not partake in any "clash of civilizations." Instead, they participate in local manifestations of global movements. Similarly, local consumerism is more than an emulation of the global. A consumer in Turkey may well be using her smart phone and wearing her fashionable branded goods of "normal" modernity (Kravets and Sandikci, 2014) while at the same time carrying a "traditional" blue-white evil eye bead in her purse. She is likely to decorate a Christmas tree in December and pray to Allah and fast during Ramadan. There is ample evidence, from Belize to Turkey, that globalization can be comprehended neither 
as a unidirectional emulation nor a simple rejection process (e.g. Abaza, 2001, 2007; Ger and Belk, 1996; Howes, 1996; Kjeldgaard and Askegaard, 2006; Miller, 1995; Sandikci and Ger, 2001, 2002, 2005, 2007, 2011;Wilk, 1995, 1998). Persons pursuing social position and belonging yield locally shaped multiple consumer cultures. These consumer cultures, embedded in dominance relations, materialize change tamed by continuity and continuity powered by transformations, which in turn breed co-existent and co-nourishing homogeneity and heterogeneity.

\section{Postcolonial relationships: The alluring foreign and the authentic local}

Despite their pitfalls, the emulation and resistance accounts accentuate the very real dominance relationships. Feelings of exclusion from and desire for First World affluence and sophistication have a historical background (de Koning, 2009). In that historical context, advertisements announce that "the world" has arrived and claim that this exclusion is being overcome - if only for the elite or the middle classes, if only in consumption.

In postcolonial studies (e.g. Bhabha, 1994; Eaton, 2004; Taussig, 1993), rather than two preexisting essences - us-Other (or local - foreign/global) - there is entanglement of "unequal times contingent, shifting, and unstable orderings" (Bhabha, 1994, p. 140). Bhabha (1994) describes mimicry as ironic and mocking emulation by dominated groups, which animates postcolonial imaginations after the end of colonization. Taussig (1993) argues that "meaning and hence power, ricocheting from West to Other, from mimesis to alterity, and back again ...can only be thought of as endless mobility" (p.249). Taussig suggests that mimesis is the basis of knowledge about the Other. Accordingly,Wilk (1999) argues that appetite for foreign goods is an upshot of the desire to know about the world. Mimetic learning about the world at any particular moment is permeated with the us-other tension, however mobile and entwined it may be.

Then, the struggle between "seductive globalism" and "authentic localism," "our culture versus the powerful and dangerous other" (Wilk, 1999, p. 248) permeates consumptionscapes. On the one hand, there is an "allure of the foreign" (Orlove, 1997), a fascination with and a trust in the foreign global. Ger, Askegaard, and Christensen (1999) report that Turkish middle class consumers regard foreign goods to be superior and using them to be a part of the world. To them, the "West" signifies modernity, advancement, orderliness, innovation, comfort, and freedom. As they eat KFCs and text with their iPhones, consumers feel they are a part of such a global modern world. Global brands are arguably embraced as a passport to global citizenship (Strizhakova, Coulter and Price, 2008). The preference for the foreign is also reflected in the adoption of foreign or foreign-sounding names for domestic products (Ger, Kravets and Sandikci, 2011).

On the other hand, there is an ambivalence about the Western Other, rooted in the history of relations with dominant Others (Bhabha, 1994; Chatterjee, 1993). The occidental has been seen as a bearer of moral threat as well as a source of innovation (Creighton, 1995) in formerly colonized geographies and elsewhere. In contemporary Turkey, the imagery of the West conjures up desire as well as fear of moral dangers and its destructive potential, and frustration, due to the EU membership process. Juxtaposed to such danger is the "authentic local."The familiarity with local products and forms deliver a sense of warmth, comfort, and security (Ger, 2005). The words of one middle class Turkish consumer is telling: "Our hearts say 'stay here, you are members of the East,' but our mind, our direction is always facing West” (Ger et al., 1999, p. 166).

Local consumers who struggle navigating seductive globalism and authentic localism are embedded in the neoliberal marketplace of global media, transnational corporations and the global-facing and local-facing local actors. The particular interplay between the desirable and/ or the dangerous foreign/global and the downgraded and/or exalted local rests on the past and 
present of particular dominance relations. Such contestations make for interactive homogenization and heterogenization, set in Taussig's "endless mobility." Accordingly, consumption reveals adaptations of transnational structures and ideologies in local contexts - "glocalization" (Robertson, 1995). In Wilk's (1995) terms, "structures of common difference," a globally common set of formats and structures controlling what is to be produced and consumed "put diversity in a common frame" (p. 111). Such structures of global dominance relations and neoliberal transnational capitalism give rise to certain similarities in consumption patterns, which show heterogeneity in their meanings and manifestations and limits.

\section{Reinvented localization and revival of imagined roots}

One way to navigate the seductive global and the comforting local is to re-form localizations (Ger and Belk, 1996; Sandikci and Ger, 2001, 2002; Ustuner, Ger and Holt, 2000). These localizations entail a search for authenticity and revival of reimagined roots, yet in a dialogue with the modern global world and its marketplace.

The last couple of decades in Turkey witnessed a revival of interest in objects and customs constructed to represent "our traditions". One fashionable "traditional" ritual is the new "henna night" - a party preceding the wedding night. Henna is a reddish brown plant-based dye used, in this case, to color brides' hands. Henna night used to be an all-female party, which used to (and still does among lower classes) reproduce patriarchy. However, the meanings produced at the new henna night entail creatively retooled old meanings, now portraying modern urban sensibilities (Ustuner, Ger and Holt, 2000). The ritual is performed in a more theatrical and playful manner with a combination of "traditional" and "modern" implements and props. While their urban middle-class parents had a simpler party on their wedding night, the offspring now want a big "traditional" wedding, including a "henna night" and a day in the Turkish baths, frolicking with nostalgia, before their party, organized by a professional firm, consistent with global trends in themed weddings yet nothing like the Turkish weddings of the past.

Like the henna night ritual, although not particularly Turkish or Islamic, but rather pagan and prevalent in the broader region, the blue-and-white evil eye bead is imagined to be "ours". Customarily, small evil eye beads have been attached on children's clothing and larger ones hung over the door, for protection against evil spirits. Now, variously sized and shaped beads, used in new forms and ways, inserted in silver or porcelain decorative objects, even on gift items for an imported celebration, Valentine's Day, are prominent.

In addition to reinvented rituals and objects construed to be Turkish, there has been a recent interest in Ottoman restaurants and cookbooks, highly popular television series on the golden era of the empire, home accessories such as cushion cases with Ottomanesque embroideries, nargile (hookah) cafés where Turkish coffee is made in coffee machines rather than the traditional pots, marbling and calligraphy classes, and buying Ottoman art at Sotheby's, London. Other examples of this Ottomania (Sandikci and Ger, 2002) include luxury hotels which make a direct reference to the Ottoman past with their architecture and decoration, restaurants serving old Ottoman cuisine, and performances named "Sultan's Night," featuring Ottoman music and belly dancing. As Öncü (2007) argues, the current interest in "our" Ottoman past cannot be divorced from transnational trends: "in the world of late capitalism ... the display and promotion of "cultural heritage' as a marketable commodity" (p. 233) is commonplace.

A more potent sense of roots has been located in Islam, accompanying its political rise in legally secular Turkey (Balkan, Balkan and Öncü, 2015; Keyman, 2007; White, 2002). Islamic firms prospered with their novel products and services such as Islamist television channels, books, music, luxury resorts, recreations clubs, and halal (lawful, by Islamic law) foods (Demir, 
Acar and Toprak, 2004; Sandikci and Ger, 2007). While these are Islam-appropriate, they are not conventional. For example, Islamic music today has hip-hop, techno, or rap, as well as the classical mystical versions. The luxury resorts have discos where all-female guests dance to Shakira or Timberlake. In urban Turkey, even the Ramadan rituals are being reinvented with a market logic and consumerist ideology (Sandikci and Omeraki, 2007).

Perhaps the most visible in everyday life has been the rise of new and fashionable veiling (Navaro-Yashin, 2002; Sandikci and Ger, 2001, 2005, 2007, 2010; Saktanber, 1994; Secor, 2002). Whereas covering used to be a mostly rural habit, now many urban women cover, and cover fashionably. For urbanites that grew up in the 1960s and 1970s Turkey and its secular ideology, covering was not a practice that they had socialized into in homes and schools. Yet, many educated middle-class women, whose mothers were not covered, chose to cover in the 1990s and 2000 s, at a time of a growing neoliberal market and rising political power of Islam. Concurrent with the emergence of a new Islamist middle class, aesthetics and personalization of the scarf has become as important as its politics and religiosity. The new veiling is a modern practice of choice that seeks continuity in religion and is fueled by the opportune neoliberal market and politics.

Whether in the form of Turkish coffee made with electric appliances, reinterpreted rituals, Islamic fashions, or halal goods, such reinventions materialize novel localizations. What are being revived are not anything that was, either in a national or religious sense, but rather a reconstructed past, origin, or authenticity, reformulated and framed in light of global relations. "Ours" is defined by drawing from many different imaginaries of pasts. Then, as Keyder (1999) argues, the main question is not what is local, but what is being reformulated as local, after years of westernization/modernization, or globalization.

The consumers and producers of these revivals are agents of change instead of solely gatekeepers of continuity. Feeding from global flows, they also construct hybrids, which are either celebrated as expressions of creativity and appropriation or disparaged as unauthentic emulative mishmashes. Some of the above examples, such as Sandikci and Ömeraki’s (2007) Christmasy Ramadan, are as much hybrids as reinventions.

\section{Global flows and local appropriation: Hybridity and recontextualization}

Other consumer navigations of the seductive global and the comforting local engender hybrids and recontextualizations. Hybridization or creolization (Bhabba, 1994; Ger and Belk, 1996; Hannerz, 1992, 1996) refer to an intercultural process of mixing and matching things from different sources and underscore the interlinked nature of cultures. They involve local appropriation of global products, technologies, and images. The mixtures entail as much struggle as fusion. Recontextualization (Ger and Belk, 1996) is another form of local appropriation where meanings and functions are transformed in ways not intended by their producers. Examples include old washing machines being used to make butter in villages in Turkey and Christmas trees decked with Disney figures decorating living rooms of the Muslim working class in Uzbekistan, year round, to make the children happy.

Hybridization is now ubiquitous. Coca-Cola served with "döner kebap" at neighborhood eateries, Islamic hip-hop, or a Monet reproduction framed with verses from the Kuran, hung on the wall of an upper middle class Islamist's home, illustrate hybrid compositions in Turkey. Such co-existent and mixed patterns, which appeared jarring twenty years ago, are now so prevalent that they no longer surprise.

Globalization-as-hybridization perspective (Pieterse, 2001) intersects with the view that globalization entails interconnectivity (Hannerz, 1996), organized by flows and scapes - mediascapes, 
finanscapes, ideoscapes, ethnoscapes, technoscapes (Appadurai, 1990). The global flows of products, media images, technologies and information, people, money, and ideas allow movement across boundaries, making them fluid. Scapes are navigated and negotiated by consumers in ways that serve their own life goals, help resolve the contradictions they face in their daily lives, such as the struggle between the allure of the foreign and the comfort of the authentic, or establish identity and difference in local social hierarchies. In this view, the local reception of global flows is creative. Flows can increase the availability of meanings and lead to an increasing globalization of fragmentation (Firat, 1997) in which the consumer has access to a multitude of resources (Jafari and Goulding, 2013) for dealing with everyday life. Hence, the multiple and decentered flows engender fragmentation, mixing, and co-existence, rather than any synthesis in the sense of resolution of opposites.

The literature has tended to either condemn (lack of purity) or celebrate (creativity and local appropriation) hybridity. However, as Pieterse (2001) argued, hybridity (and global consumptionscapes) needs to be theorized rather than celebrated or condemned.

\section{Beyond hybridity and "flow speak"}

Hybridity and global flows emphasize interplay (Pieterse, 2001) and provide a non-essentialist, non-dualistic, and dynamic notion of culture and identity that problematize boundaries. However, the entailed fluidity notions ignore the importance of having a coherent sense of belonging to one's class, religion, ethnicity, or nation. The prevailing overemphasis on mobility and deterritorialization overlooks issues of belonging and social relations. "Flow speak," by simply including people in "ethnoscapes", "precludes the question of social participation and the deeper meaning of social existence" (Bude and Dürrschmidt, 2010, p. 482).

Secondly, the flow and hybridity speak sidestep power differences. However, flows are not symmetric: there are more flows from the dominant to the dominated locales than the other way around - more KFCs in Turkey than Turkish restaurants in the USA. In addition to importing popular culture from the dominant center (Ger, 1997), cultural practices are reappropriated in their places of origin "after a process of sanctioning in (what is most often) the Western hotbed of consumer culture production" (Askegaard and Eckhardt, 2012, p. 46). For example, homemakers in Turkey switched from their usual olive oil to the advertised new Western sunflower oil in the 1980s and then back to olive oil in the 2000s, after it was reformulated to be a fashionable and healthy Mediterranean item. Although the periphery is "allowed" to talk back in cultural production, the conversation is not symmetrical. Moreover, taking notice of a local culture usually morphs into commodification of that culture (Spivak, 1988), dependent on notions of "cultural and aesthetic authenticity" (Root, 1996, p. 69), which are again defined by the core.

In addition, flows involve a series of symbolic translations across locations rather than mechanistic movement along inert channels of passage (Rajagopal, 2001). In such translations, disjunctures in flows are used to the advantage of those powerful in transnational networks. Dominant "global structures of common difference" (Wilk, 1995) such as market institutions and their consumerist ideology define what types of diversity and hybrids will diffuse and what kinds will be submerged or suppressed. Consumers and producers come to organize their lives along similar institutional arrangements created by globalizing power blocs, such as transnational corporations.

Furthermore, while flows of multiple and counterveiling discourses leave space for consumer resistance and creativity (Thompson and Haytko, 1997), at least for consumers with appropriate cultural capital, they also reinforce structures of inequality, globally and locally. Global flows 
"feed into local social hierarchies and are taken up as forms of cultural distinction" (de Koning, 2009, p. 194). Globalization amplifies awareness of a first (class) world and the experience of exclusion from it as well as the social and economic polarization within cities: parts of the city that serve global networks are increasingly disconnected from national economies, and integrated into the global networks (de Koning, 2009). Given that consumption can empower and connect people depending on resources such as time, skill, and knowledge, the dominated, the migrant, the lower class, the less refined rural are excluded form social links to the local or the global world. Thus, we circle back to transnational and domestic power and affiliation relations.

Thirdly, "flow speak" and hybridity speak forget the historicity of the local and fail to note the multiple internal Others and tensions. Yet, the accelerating impact of globalization forces inhabitants of a country to position their own identities vis-à-vis others in that country (Keyder, 1999). The real clash may well occur not between the local and global, but between the local and local systems of meanings (Jafari and Goulding, 2013). Identity being relational, the hybridized identity needs its others. Hence, what needs to be accounted for are the formation and interaction of Others within a society that encounters marketization and globalization - changes which interrogate sociocultural ideals, norms, and notions of normality.

\section{Internal tensions and "Others" within the local as it navigates the global}

Studies from Turkey (e.g. Kandiyoti and Saktanber, 2002; Kravets and Sandikci, 2014; Kuruoglu and Ger, 2015; Türe and Ger, 2016) reveal the role of the historical context in forming the relevant Others that pertain to consumption anxieties, desires, and patterns. The historical relations with Europeans, Arabs, and Iranians, interpreted with diverse ideologies, serve different political purposes in the present. These imaginaries entail the good old days of Islamic ways of life and the glamour of the Ottoman past, or the purity of the Anatolian (or Turkish) peoples, or the backwardness of the Late Ottomans versus the progressive and enlightened reforms of Atatürk. Such a past is in this present (Friedman, 1992) intertwined with asymmetrical global flows, which further dominance structures. The "global" imaginaries include the USA and Europe in the minds of Western-oriented seculars, the Gulf States and Muslim Asian countries as well as the USA and Europe in the minds of Islamists. Such pasts in presents and ensuing imaginations of different futures set the stage for inclusion and exclusion relations between the urbanites and the peasants, the upscale and the downscale, and the secular-religious groups.

\section{The rural Other in Turkey}

A basic clash since the nineteenth- and twentieth-century modernizations has been between the city, the center, and the countryside, the periphery (Mardin, 1973). Whereas the city connotes progressive modernity, the village signifies ignorant backwardness (Türe and Ger, 2016). Given that literacy continues to be a serious issue, the relative deprivation of villagers in education, health services, and transportation increases the social distance between the city and the village. Globalization fosters that distance and self-Orientalization tendencies. New imported products, shopping malls, five-star hotels, gated communities, and foreign cuisine restaurants proliferated in the 1990s in the cities (Kravets and Sandikci, 2014), further dissociating urban lives from rural ones (and middle classes from lower classes).

A rapid urbanization, along with the 1980s economic liberalization, raised the urban population from $30 \%$ to $70 \%$ in four decades (Icduygu, 2004). Rural migrants typically settled in squatter houses at the periphery of the city and worked in the informal economy. With increasing 
urban poverty, many of these now-urban families faced deprivation and became subject to social exclusion (Bugra and Keyder, 2003). Today, over 50\% of the urban population in Ankara, Istanbul and Izmir, the three biggest cities, resides in squatter settlements, which have been stigmatized as ghettos and their residents as the "threatening Other," attacking the city's modern values and social order (Erman, 1998). Despite recent improvements in infrastructure and hence their living conditions and legal recognition of their status (Baslevent and Dayoglu, 2005), they remain socially and economically excluded. As Ustuner and Holt (2007) demonstrate, the hegemonic urban culture conflicts with the rural culture. They find that some rural-to-urban migrants reconstitute the village culture in the city; others engage in the urban consumer culture and try to adopt urban consumption patterns. However, rural-to-urban migrants remain dominated (Ustuner and Holt, 2007). They remain the Other in the eyes of the urbanites who want to distance themselves from the rural past and still-rural scenes. A recent youth subculture who struggle to differentiate themselves from the squatter area culture with their clothing and grooming styles have become subjects of mockery among their own parents and the urbanites (Yaman, 2013).

As cities became crowded with rural immigrants and rural aesthetics, urban middle classes moved to gated communities (Datta, 2014; Öncü, 1997). Öncü suggests that this is a strategy to protect their middle/upper-class status and move away from the cultural pollution, vulgarity, and ugliness of what once used to be their city. Ger and Yenicioglu (2004) note the links between attributions of dirtiness and rural-urban status as well as social class status. Hence, the rural-urban tension and Othering the peasants are as much a matter of modernizing urbanization as social class.

\section{Class-based Others in Turkey}

Social class continues to be germane to the formation of individual identities to the extent that people construct their identities in relational terms (Karademir-Hazir, 2014a, b). Consumers use global products, brands, and styles to articulate local social distinctions. Karademir-Hazir finds that, despite the presence of multiple ways to be modern and traditional, despite the proliferating commercial services aiming to manage appearance based on global images, "there are still compelling conditions hindering one's playful engagement with the related consumption domains" and class remains embodied in Turkey (Karademir-Hazir, 2014a, p. 17). She uncovers four embodiment clusters: conspicuous modern (upper middle class, with ties to Western cultural patterns and global brands), reserved traditionals (low brow), modern and modest (pious), and constrained display. These four clusters are apt to be the Other for each other.

Even within one social class there appear to be subgroups that are each other's Other. Turkish middle class consumers with larger volumes of capitals draw stronger boundaries built upon judgments of "good taste", by distancing themselves from the "uncultured" Others of the same class (Karademir-Hazir, 2014b). Similarly, Üstüner and Holt's (2010) investigation of two factions of Turkish upper middle class women indicates that high culture consumers use Western lifestyles to distinguish themselves from low culture consumers who mimic the lifestyles of the domestic elites.

Kravets and Sandikci (2014) report yet another recipe for distinction, which simultaneously provides a sense of global belonging, employed by the new middle class (NMC). Through "formulaic creativity" (rather than emulation or resistance) consumers attempt to align with the global middle. NMC consumers "seek a secure place in a new society by embracing the shared standard, which includes ... a modern apartment and a set of goods (e.g. a Volkswagen car, an iPhone, a Louis Vuitton bag, a Samsung television)" (p. 137). In this case, "consumers assimilate 
one another into 'people like us' and imagine the middle as a site of normality and comfort" (p. 126). If attained, global normality provides a consumption-driven social connection to the world, among those who are included.

Rare exceptions to such exclusionary inclusions include the democratizing tea (Ger and Kravets, 2009) and the "high-society bazaars," which evolved from conventional lower class versions (Vicdan and Firat, 2015). Like the tea, the "high-society bazaar," where lower classes and omnivore middle classes experience each other, are social levelers.

\section{Others of the urban faithful and Islamists in Turkey}

The rising clash between the seculars and faithful/Islamists is a political, moral, and normative issue. After over a century of westernization, the secular modernization has yielded to an Islamladen neoliberal globalization. To Islamists, secularism connotes a rejection of religion - absence of Islamic law. To secular urbanites, separation of state and religion, and hence relocation of religion from the public to the private sphere, is a condition of modernity. For them, not Islam itself, but Islamic ways of life are associated with the past, the village, and retrogression. Hence, the so-called "secularists" and "Islamists" adhere to very different worldviews, ideals, lifestyles and consumption practices. With the populist and Islamist Justice and Development Party (JDP) at the helm, in the last couple of decades Islamist ideology and ways of life moved from the peripheries of Turkey to its urban centers and has eventually become dominant (Balkan, Balkan and Öncü, 2015; Karaman, 2013; Keyman, 2007; Toprak, 1984). Under JDP, neoliberalism became entrenched, so did a new Muslim elite; everyday lives have become marketized as well as Islamized with a renewed conservatism: neoliberal and Islamist values, practices, and codes of conduct have become normalized, routinized, mainstream, and hegemonic.

The Islamist elite and middle class, aligned with the local and global networks of economic and political power, and the urban seculars Other each other with a vengeance. This struggle, shaped locally and globally, is far more substantial than with any global Other. Drawing from Islam and local and global cultural resources and claiming their own modernity, the Muslim elite crafts new consumption patterns - modern, casual, and trendy clothes, natural goods, traditional cuisine, Ottoman artifacts, alternative vacations, and traveling. They adopt fashionable styles of covering to distinguish their modern selves morally from secular moderns, and employ fashion to routinize covering. Sandikci and Ger (2010) reveal that there is now a new habitus, "informed by Islamic as well as modern sensitivities" (p. 31). Accordingly, the so-called secular and Islamist taste structures are in competition.

Moreover, the secular urbanites are not the only Others for the Islamist elites. They seek to distance themselves from other faithful or Islamist groups in the way they consume. While they favor halal products like all other Muslims, they simultaneously seek progress and modernization, construed in terms of shopping malls, global brands, smart phones, and Facebook. Their Muslim Others include three groups: the more strict and "backward" Muslims who wear the "nonsensical" black chador and who reject Western brands (Izberk-Bilgin, 2012); the "traditional" villagers and the rural-to-urban migrants who live their lives in habitual manners; and the Islamist "new rich" who display "gaudy and pretentious" styles.

\section{How to study always-local global consumption?}

The issues identified suggest that, to understand global-local encounters, we need to shift the perspective from flows and interplay to dominance and belonging relations - from hybridity as a mere blend to hybridity embedded in and embodying power relations (as Kjeldgaard and 
Askegaard [2006] have done) and social bonds. Appadurai's flows "have to be located in global and local histories of inequality and dominance" (de Koning, 2009, p.194). This is critical given that local inequalities have been rising under current politics of neoliberal globalization (Pieterse, 2001).

Moreover, we have to emphasize the dominance and belonging relations within societies as they navigate intensifying global connections. In doing so, we have to take materiality (Kravets and Örge, 2010; Türe and Ger, 2016) and emotionality (Kuruoglu and Ger, 2015) as seriously as we do meanings and narratives. Consumption of global brands and reinvented, recontextualized, or appropriated hybrid products entail very material and affective dominance and belonging relations - and not merely symbolic and fluid play.

While studying the global-local encounters in consumption, we must start with the lived experiences as well as the structuring context (Askegaard and Linnet, 2011;Venkatesh, 1995), considering consumers' agentic capabilities and the limits thereof. A focus on experiences in configuring structures calls for historicity and a temporal perspective: the locals' multiple imaginaries of their pasts, presents, and futures (Türe and Ger, 2016). Actually, neither of these are novel ideas: Friedman wrote "cultural realities are always produced in specific sociohistoric contexts" and discussed "the past in the present" and "the past in the future" in 1992. Lambek (2011) provides further ideas as to how to be "attuned to the temporality and depth of the local" (p. 209). As he argues, we must rethink "the local" "as a structure of feeling, affect, temporality and relatedness" (p. 197) and understand local consumers through the "sedimentation of acts" (p. 216) and their consequences.

"Catching the local" (Lambek, 2011) does not only apply to the peripheries of the world such as Turkey, but also to the dominant centers such as the USA. It would be telling if we study how, for example, North Americans navigate their encounters with, for instance, Chinese products, brands, and images. So far, consumer researchers examined North American locals usually as cosmopolitans and expats (e.g. Thompson and Tambyah, 1999). An exception is Thompson and Arsel's (2004) study of a hegemonic brandscape, structuring consumer experiences of glocalization. It is perhaps timely to conduct such refreshing studies, for example, of Asian brandscapes in the USA.

Just like remembering Friedman, recalling multi-sited ethnography (Marcus, 1995) is also timely. Consider Mintz's (1985) brilliant historical work on the taste for sugar and the underlying colonial relations, and more recently Foster's (2008) study following the social life of soft drinks from New York to New Guinea. We consumer researchers (see Ger and Csaba, 2000; and Kjeldgaard, Csaba and Ger, 2006 for exceptions) have not yet taken full advantage of this methodology.

Finally, as Bude and Dürrschmidt (2010) argue, we must complement the overemphasis on mobility and deterritorialization with a focus on issues of belonging. We have seen examples of consumers' pursuit of belongingness, being part of the world - even if merely with their consumption, or global citizenship via global brands, or reinventing authenticities to attain the comfort of local social links. A focus on social connections as well as fluidity converges with the suggestion that we should probe the continuities within changes and vice versa.

We can revive the stifled consumer research on globalization by examining the lived experiences of consumers and teasing out the historical and current structures that make an experience and/or a consequence what it has come to be (Karababa and Ger, 2011; Sandikci and Ger, 2010), continuities as well as discontinuities (Schatzki, 2002; Türe and Ger, 2016), similarities as well as differences (Kravets and Sandikci, 2014), affective structures (Ahmed, 2004; Kuruoglu and Ger, 2015), and dominance and belonging relations. Teamwork across different locales will make such investigations more reflective, fruitful, and fun. 


\section{References}

Abaza, M. (2001), 'Shopping Malls, Consumer Culture and the Reshaping of Public Space in Egypt,' Theory, Culture and Society, vol. 18, no. 5, pp. 97-122.

Abaza, M. (2007), 'Shifting Landscapes of Fashion in Contemporary Cairo,' Fashion Theory, vol. 11, no. 2-3, pp. 281-98.

Ahmed, S. (2004), 'Affective Economies,' Social Text, vol. 22, no. 2, pp. 117-139.

Appadurai, A. (1990), 'Disjuncture and Difference in the Global Cultural Economy', Theory, Culture and Society, vol. 7, pp. 295-310.

Askegaard, S. and Eckhardt, G.M. (2012), 'Glocal Yoga: Re-appropriation in the Indian Consumptionscape,' Marketing Theory, vol. 12, no. 1, pp. 45-60.

Askegaard, S. and Linnet, J. T. (2011), 'Towards an Epistemology of Consumer Culture Theory: Phenomenology and the Context of Context,' Marketing Theory, vol. 11, no. 4, pp. 381-404.

Balkan, N., Balkan, E. and Öncü, A. (eds) (2015), The Neoliberal Landscape and the Rise of Islamist Capital in Turkey, New York: Berghahn Books.

Barber, B. R. (1996), Jihad vs. McWorld: How Globalization and Tribalism are Reshaping the World, New York: Ballantine.

Baslevent, C. and Dayoglu, M. (2005), 'The Effect of Squatter Housing on Income Distribution in Urban Turkey, Urban Studies, vol. 42, no. 1, pp. 31-45.

Bhabha, H. (1994), The Location of Culture, London: Routledge.

Bude, H., and Dürrschmidt, J. (2010), 'What's Wrong with Globalization?: Contra "Flow Speak"-Towards An Existential Turn in the Theory of Globalization,' European Journal of Social Theory, vol. 13, no. 4, pp. 481-500.

Bugra, A. and Keyder, C. (2003), New Poverty and the Changing Welfare Regime of Turkey, Ankara: UNFP Office in Turkey.

Chatterjee, P. (1993), The nation and its fragments: Colonial and postcolonial histories (Vol. 11), Princeton: Princeton University Press.

Creighton, M. R. (1995), 'Imagining the Other in Japanese Advertising Campaigns', in J. G. Carrier (ed) Occidentalism: Images of the West, Oxford: Clarendon Press, pp. 135-160.

Datta, A. (2014), 'Gendered Nature and Urban Culture: The Dialectics of Gated Developments in Izmir, Turkey', International Journal of Urban and Regional Research, vol. 38, no. 4, pp. 1363-1383.

de Koning, A. (2009), Global Dreams: Space, Class, and Gender in Middle-Class Cairo, Cairo: American University in Cairo Press.

Demir, Ö., Acar, M. and Toprak, M. (2004), 'Anatolian Tigers or Islamic Capital: Prospects and Challenges,' Middle Eastern Studies, vol. 40, no. 6, pp. 166-188.

Eaton, N. (2004), 'Between Mimesis and Alterity: Art, Gift, and Diplomacy in Colonial India, 1770-1800,' Comparative Studies in Society and History, vol. 46, no. 4, pp. 816-844.

Erman, T. (1998), 'Becoming 'Urban' or Remaining 'Rural': The Views of Turkish Rural to Urban Migrants on the 'Integration' Question,' International Journal of Middle Eastern Studies, vol. 30, no. 4, pp. 541-561.

Firat, A. F. (1997), 'Globalization of Fragmentation: A Framework for Understanding Contemporary Global Markets,' Journal of International Marketing, vol. 5, no.v2, pp. 77-86.

Friedman, J. (1992), 'The Past in the Future: History and the Politics of Identity, American Anthropologist, vol. 94 , no. 4, pp. 837-859.

Foster, R. J. (2008), Coca-Globalization: Following Soft Drinks from New York to New Guinea, New York: Palgrave MacMillan.

Ger, G. (1997), 'Human Development and Humane Consumption: Well-Being Beyond the Good Life,' Journal of Public Policy and Marketing, vol. 16, no 1, pp. 110-125.

Ger, G. (2005), 'Warming: Making the New Familiar and Moral,' Ethnologia Europea: Journal of European Ethnology, vol. 35, no. 1-2, pp. 19-22.

Ger, G. (2013), 'Islamic Marketing at the Nexus of Global Markets-Religions-Politics and Implications for Research,' Marketing Theory, vol. 13, no. 4, pp. 493-499.

Ger, G., Askegaard and S. Christensen, A. (1999), 'Experiential Nature of Product-Place Images: Image as a Narrative,' in E. Arnould and L. Scott (eds) Advances in Consumer Research, Provo, UT: Association for Consumer Research, vol. 26, pp. 165-169.

Ger, G. and Belk, R.W. (1996), 'I'd Like to Buy the World a Coke: Consumptionscapes of the "Less Affluent World", Journal of Consumer Policy, vol. 19, no. 3, pp. 271-304. 
Ger, G. and Csaba, F.F. (2000), 'Flying Carpets: The Production and Consumption of Tradition and Mystique,' in S. J. Hoch and R. J. Meyers (eds) Advances in Consumer Research, Provo, UT: Association for Consumer Research, vol. 27, pp. 132-137.

Ger, G. and Kravets, O. (2009), 'Special and Ordinary Times: Tea in Motion,' in E. Shove, F.Trentmann and R.Wilk (eds) Time, Consumption and Everyday Life, Oxford: Berg, pp. 189-202.

Ger, G., Kravets, O. and Sandikci, O. (2012) 'International Marketing at the Interface of the Alluring Global and the Comforting Local,' in L. Peñaloza, N. Toulouse, L. M. Visconti (eds) Marketing Management: A Cultural Perspective, London: Routledge, pp. 30-42.

Ger, G. and Yenicioglu, B. (2004), 'Clean and Dirty: Playing with Boundaries of Consumer's Safe Havens,' in B. E. Kahn and M. F. Luce (eds) Advances in Consumer Research, Provo, UT: Association for Consumer Research, pp. 2462-2467.

Gökarıksel, B. and Secor, A.J. (2009), 'New Transnational Geographies of Islamism, Capitalism and Subjectivity: The Veiling-Fashion Industry in Turkey,' Area, vol. 41, no. 1, pp. 6-18.

Hannerz, U. (1992), Cultural complexity: Studies in the social organization of meaning, New York: Columbia University Press.

Hannerz, U. (1996), Transnational Connections, London: Routledge.

Howes, D. (ed) (1996), Cross-Cultural Consumption, London: Routledge.

Huntington, S. P. (1996), The Clash of Civilizations and the Remaking of World Order, New York: Simon \& Schuster.

İçduygu, A. (2004), 'From Nation-Building to Globalization: An Account of the Past and Present in Recent Urban Studies in Turkey,' International Journal of Urban and Regional Research, vol. 28, no. 4, pp. 941-951.

Izberk-Bilgin, E. (2012), 'Infidel Brands: Unveiling Alternative Meanings of Global Brands at the Nexus of Globalization, Consumer Culture, and Islamism,' Journal of Consumer Research, vol. 39, no. 4, pp. 663-687.

Jafari,A. and Goulding, G. (2013), 'Globalization, Reflexivity, and the Project of the Self: A Virtual Intercultural Learning Process,' Consumption Markets and Culture, vol. 16, no. 1, pp. 65-90.

Kandiyoti, D. and Saktanber A. (2002), Fragments of Culture: The Everyday of Modern Turkey, London: IB Tauris.

Karababa, Eminegül and Güliz Ger (2011), 'Early Modern Ottoman Coffeehouse Culture and the Formation of the Consumer Subject,' Journal of Consumer Research, vol. 37, no. 5, pp. 737-760.

Karademir-Hazir, I. (2014a), 'How Bodies are Classed: An Analysis of Clothing and Bodily Tastes in Turkey,' Poetics, vol. 44, pp. 1-21.

Karademir-Hazir, I. (2014b), 'Boundaries of Middle-Class identities in Turkey', The Sociological Review, vol. 62 , no. 4, pp. 675-697.

Karaman, O. (2013), 'Urban Neoliberalism with Islamic Characteristics,' Urban Studies, vol. 50, no. 16, pp. 3412-3227.

Keyder, C. (ed) (1999), Istanbul, Between the Global and the Local, Lanham, Boulder, New York, Oxford: Rowman and Littlefield Publishers.

Keyman, F. (2007), 'Modernity, Secularism and Islam:The Case of Turkey,' Theory, Culture and Society, vol. 24, no. 2, pp. 215-34.

Kjeldgaard, D. and Askegaard, S. (2006), 'The Glocalization of Youth Culture:The Global Youth Segment as Structures of Common Difference,' Journal of Consumer Research, vol. 33, pp. 231-247.

Kjeldgaard, D., Csaba, F.F and Ger, G. (2006), 'Grasping the Global: Multi-sited Ethnographic Market Studies,' in R.W. Belk (ed) Handbook of Qualitative Research Methods in Marketing, Cheltenham, UK: Edward Elgar Publishing, pp. 521-533.

Kravets, O. and Örge, Ö. (2010), 'Iconic Brands: A Socio-Material Story,'Journal of Material Culture, vol. 15, no. 2, pp. 205-232.

Kravets, O. and Sandikci, Ö. (2014), 'Competently Ordinary: New Middle Class Consumers in Emerging Markets,' Journal of Marketing, vol. 78, pp. 125-140.

Kuruoglu, P. A. and Ger, G. (2015), 'An Emotional Economy of Mundane Objects,' Consumption Markets \& Culture, vol. 18, no. 3, pp. 209-238.

Lambek, M. (2011), 'Catching the Local', Anthropological Theory, vol. 11, no. 2, pp. 197-221.

Marcus, G. E. (1995), 'Ethnography in/of the World System: The Emergence of Multi-sited Ethnography,' Annual Review of Anthropology, vol. 24, pp. 95-117.

Mardin, S. (1973), 'Center-Periphery Relations: A Key to Turkish Politics?' Daedalus, vol. 102 (Winter), pp. 169-90.

Miller, D. (1995), Worlds apart: Modernity Through the Prism of the Local, London: Routledge.

Mintz, S.W. (1985), Sweetness and Power, New York:Viking. 
Navaro-Yashin, Y. (2002), 'The Market for Identities: Secularism, Islamism, Commodities,' in D. Kandiyoti and A. Saktanber (eds) Fragments of Culture: The Everyday of Modern Turkey, London: I. B. Tauris, pp. 221-53.

Öncü,A. (1997), 'The Myth of the Ideal Home Travels Across Cultural Borders to Istanbul,' in A. Öncü and P. Weyland (eds) Space, Culture, Power: Struggles Over New Identities In Globalizing Cities, London: ZED, pp. 56-72.

Öncü, A. (2007), 'The Politics of Istanbul's Ottoman Heritage in the Era of Globalism: Refractions through the Prism of a Theme Park,' in B. Drieskens, F. Mermier and H. Wimmen (eds) Cities of the South: Citizenship and Exclusion in the 21st Century, London, Beirut: Saqi Books, pp. 233-264.

Orlove, B. (1997), The Allure of the Foreign: Imported Goods in Postcolonial Latin America, Ann Arbor: University of Michigan Press.

Pieterse, J. N. (2001), 'Hybridity, So What? The Anti-Hybridity Backlash and the Riddles of Recognition,' Theory, Culture \& Society, vol. 18, no. 2-3, pp. 219-245.

Rajagopal, A. (2001), Politics After Television: Hindu Nationalism and the Reshaping of the Public in India, Cambridge: Cambridge University Press.

Ritzer, G. (1993), The McDonaldization of Society, NewBury Park, CA: Pine Forge Press.

Robertson, R. (1995), 'Glocalization:Time-Space and Homogeneity-Heterogeneity', in M. Featherstone, S. Lash and R. Robertson (eds) Global Modernities, London: Sage, pp. 25-44.

Root, D. (1996), Cannibal Culture: Art, Appropriation, and the Commodification of Difference, Boulder, CO: Westview Press.

Saktanber, A. (1994), 'Becoming the 'Other' as a Muslim in Turkey: Turkish Women vs. Islamist Women,' New Perspectives on Turkey, vol. 11 (Fall), pp. 99-134.

Sandikci, Ö. and Ger, G. (2001), 'Fundamental Fashions:The Cultural Politics of the Turban and the Levi's', in J. Meyers-Levy and M. Gilly (eds) Advances in Consumer Research, Provo, UT: Association for Consumer Research, vol. 28, pp. 146-150.

Sandikci, Ö. and Ger, G. (2002), 'In-Between Modernities and Postmodernities: Theorizing Turkish Consumptionscape,' in S. Broniarczyk and K. Nakamoto (eds) Advances in Consumer Research, Provo, UT: Association for Consumer Research, vol. 29, pp. 465-470.

Sandikci, Ö. and Ger, G. (2005), 'Aesthetics, Ethics and the Politics of the Turkish Headscarf', in S. Kuechler and D. Miller (eds) Clothing as Material Culture, Oxford: Berg, pp. 61-82.

Sandikci, Ö. and Ger, G. (2007), 'Constructing and Representing the Islamic Consumer in Turkey', Fashion Theory, vol. 11, no. 2-3, pp. 189-210.

Sandikci, Ö. and Ger, G. (2010), 'Veiling in Style: How Does a Stigmatized Practice Become Fashionable?' Journal of Consumer Research, vol. 37, no. 1, pp. 15-36.

Sandikci, Ö. and Ger, G. (2011), 'Islam, Consumption and Marketing: Going Beyond the Essentialist Approaches,' in O. Sandikci and G. Rice (eds) Handbook of Islamic marketing, Cheltenham, UK: Edward Elgar, pp. 484-501.

Sandikci, Ö. and Jafari, A. (2013), 'Islamic Encounters in Consumption and Marketing,' Marketing Theory, vol. 13 , no. 4 , pp. 411-420.

Sandikci, Ö. and Ömeraki, S. (2007), 'Globalization and Rituals: Does Ramadan Turn Into Christmas?' Advances in Consumer Research, vol. 34, pp. 610-15.

Sandikci, Ö. and Rice, G. (eds) (2011), Handbook of Islamic Marketing, Cheltenham, UK: Edward Elgar Publishing.

Schatzki,T. R. (2002), The Site of the Social: A Philosophical Account of the Constitution of Social Life and Change, University Park, PA:The Pennsylvania State University Press.

Secor, A. J. (2002), 'The Veil and Urban Space in Istanbul:Women's Dress, Mobility and Islamic Knowledge,' Gender, Place and Culture, vol. 9, no. 1, pp. 5-22.

Spivak, G. C. (1988), In Other Worlds: Essays in Cultural Politics, New York: Routledge.

Strizhakova, Y., Coulter, R. and Price, L.L. (2008), 'Branded Products As a Passport to Global Citizenship: Perspectives from Developed and Developing Countries,' Journal of International Marketing, vol. 16, no. 4, pp. $57-85$.

Taussig, M. (1993), Mimesis and Alterity: A Particular History of the Senses, New York: Routledge.

Thompson, C. J. and Arsel, Z. (2004), 'The Starbucks Brandscape and Consumers' (Anticorporate) Experiences of Glocalization,' Journal of Consumer Research, vol. 31 (Dec), pp. 631-642.

Thompson, C. J. and Haytko, D. L. (1997), 'Speaking of Fashion: Consumers' Uses of Fashion Discourses and the Appropriation of Countervailing Cultural Meanings,' Journal of Consumer Research, vol. 24 (June), pp. 15-42. 
Thompson, C.J. and Tambyah, S.K. (1999), 'Trying to Be Cosmopolitan,' Journal of Consumer Research, vol. 26 (December), pp. 214-241.

Toprak, B. (1984), 'Politicisation of Islam in a Secular State: The National Salvation Party in Turkey,' in S. A. Arjomand (ed) From Nationalism to Revolutionary Islam, New York: SUNY Press, pp. 119-133.

Türe, M. and Ger, G. (2016), 'Continuity through Change: Navigating Temporalities through Heirloom Rejuvenation,' Journal of Consumer Research, vol. 43, no. 1, pp. 1-25, forthcoming.

Turner, B. (1994), Orientalism, Postmodernism and Globalism, London: Routledge.

Üstüner, T., Ger, G., and Holt, D. (2000), 'Consuming Ritual: Reframing the Turkish Henna-Night Ceremony,' in S. J. Hoch and R. J. Meyers (eds) Advances in Consumer Research, Provo, UT: Association for Consumer Research,Vol. 27, pp. 209-214.

Üstüner, T. and Holt, D.B. (2007), 'Dominated Consumer Acculturation: The Social Construction of Poor Migrant Women's Consumer Identity Projects in a Turkish Squatter', Journal of Consumer Research, vol. 34, no. 1, pp. 41-55.

Üstüner, T. and Holt, D.B. (2010), 'Toward a Theory of Status Consumption in Less Industrialized Countries,' Journal of Consumer Research, vol. 37 (June), pp. 37-56.

Venkatesh, A. (1995), 'Ethnoconsumerism: A New Paradigm to Study Cultural and Cross-Cultural Consumer Behavior', in J. Arnold Costa and G. Bamossy (eds) Marketing in a Multicultural World: Ethnicity, Nationalism, and Cultural Identity, Thousand Oaks, CA: Sage Publications, pp. 26-67.

Vicdan, H. and Firat, A.F. (2015), 'Evolving Desire to Experience the Social 'Other': Insights from the High-Society Bazaar,' Journal of Consumer Culture, vol. 15, no.2, pp. 248-276.

Wilk, R. (1995), 'Learning to be Local in Belize: Global Systems of Common Difference', in D. Miller (ed) Worlds Apart: Modernity through the Prism of the Local, London: Routledge, pp. 110-133.

Wilk, R. (1998), 'Emulation, Imitation, and Global Consumerism,' Organization E Environment, vol. 11, no. 3, pp. 314-333.

Wilk, R. (1999), “Real Belizean Food”: Building Local Identity in the Transnational Caribbean,' American Anthropologist, vol. 101, no. 2, pp. 244-255.

White, J. B. (2002), Islamist Mobilization in Turkey: A Study in Vernacular Politics, Seattle: University of Washington Press.

Yaman, Ö. M. (2013), Apaci Genclik, Istanbul: Acilim Kitap. 